\title{
Comparative Assessment of Sustainable Energy Development in the Czech Republic, Lithuania and Slovakia
}

- Štreimikiene Dalia, Mikalauskiené Asta, Mikalauskas Ignas

\begin{abstract}
Sustainable energy development and its evaluation is a key resource in learning and understanding the policies implemented by the European Commission and how they work while comparing countries within sustainable energy indicators in the area of sustainable energy. The competitiveness of countries is directly related to the progress achieved in implementing sustainable energy development as the energy sector has great significance for the future development of the country. The energy sector is crucial for economic growth and has a major impact on the environment. Sustainable energy development permits the decoupling of economic growth from energy consumption and the decoupling of energy consumption from atmospheric pollution. This paper views the concept of sustainable energy development and policies that are in place of this topic. It also compares the Czech Republic, Lithuania, and Slovakia within the boundaries of the following sustainable energy development indicators: sustainable consumption and production, marking the production of energy; climate change and energy, marking GHG emissions and the share of renewable energy in gross final energy consumption; sustainable transport, marking the energy consumption of transport relative to GDP.
\end{abstract}

Keywords: Czech Republic, Lithuania and Slovakia, sustainable energy development, comparative assessment. JEL Classification: F68, N74, Q56.

\section{INTRODUCTION}

Sustainability was a major topic in the 20th century; it developed as a result of vast resources being used during the Industrial Revolution without any consideration about the future, as well as a fast-growing population and its challenges and demands, which will rise over time. As concern grew about human survival over the next century, it was inevitable for brilliant minds to develop some sort of understanding of how to determine what is right and what is wrong, to develop a concept of sustainability and sustainable development.

When directing what is sustainable development, there was a need for certain sustainable development policies to appear in countries, so that it would be in the frames of government to promote and sustain these policies in order to follow the whole idea of sustainability.

The energy sector is directly related to the competitiveness of countries as this sector is crucial for sustainable development, i.e. energy production and consumption have the greatest impact on the environment in terms of climate change and atmospheric pollution (Streimikiene \& Balezentiene, 2012). On the other hand energy is the main driver of economic growth and therefore analysis of sustainable energy development can be assessed by analyzing the decoupling of GDP 
from energy consumption and the decoupling of energy consumption from atmospheric pollution, including GHG emissions (Streimikiene et al., 2011; Streimikiene, 2013). Increased energy efficiency allows the decoupling of economic growth from energy consumption to be achieved and increased usage of renewable energy sources allows the decoupling of energy consumption from GHG emissions to be achieved. Both policies related to increased energy efficiency and the use of renewable energy sources are considered as policies to promote sustainable energy development and the competitiveness of countries (Cicea et al., 2014; Ibanez-Fores et al., 2014; Vasauskaite \& Streimikiene, 2014; Streimikiene \& Sarvutyte-Grigaliuniene, 2013).

When policies to promote sustainable energy development exist, indicators of sustainable energy development can be applied to indicate how to determine the boundaries and the framework of sustainable energy development. With these indicators, it becomes easier to evaluate different sections of sustainability and to compare the development of different countries towards sustainability over the years (Banos et al., 2011).

The hypothesis for each of the countries is that sustainable energy development initiatives have successfully promoted the energy sustainability of the country and that is represented in the data gathered throughout the years. If sustainable energy development is successfully established, the data will show positive feedback, and if the feedback is negative, this means that the policies that have been implemented did not work properly and did not bring positivity into the corresponding sustainable energy development issues.

The research goal is to compare these indicators over three main sustainability spheres in the energy sector - economic, social, and environmental - between the Czech Republic, Lithuania, and Slovakia. All three dimensions provide a view of the sustainable energy development path that these countries were and are on, leading towards a more sustainable energy future for their citizens. The main tasks to achieve the goal are: to present a concept of sustainable energy development and policies to promote sustainable energy development; to define the main indicators of sustainable energy development, and to assess and compare the trends of the main indicators of sustainable energy development in Lithuania, the Slovak Republic, and the Czech Republic.

\section{SUSTAINABLE ENERGY DEVELOPMENT}

\subsection{Concept of sustainable energy development}

The concept of sustainable energy development has developed since it was first mentioned in the Brundtland Report, called "Our Common Future". It was formulated as "Development that meets the needs of the present without compromising the ability of future generations to meet their own needs" (Brundtland et al., 1987).

The concept is based on the prerequisite that people within communities follow three main systems - economic, social, and environmental (Munasinghe, 2007) - systems which are connected to each other and must be kept in balance and harmony in order for the community to continue developing. Even though the concept seems clear, a quarter of the world's population currently live without electricity and this number has hardly changed in absolute terms since 1970 (Ahuja \& Tatsutani, 2009). 
However, the sustainable development approach additionally argues that "real" improvement cannot occur in Third World countries unless the strategies which are being formulated and implemented are environmentally sustainable in the long term, are consistent with social values and institutions, and encourage "grassroots" participation in the development process (Barbier, 1987).

Sustainable energy development is the ultimate goal of modern society in order to meet the growing demand for new energy sources. It was recognized that the complexity of the global system requires special attention to the interaction that exists between life support systems (Afgan et al., 2000).

2.2 Policies to promote sustainable energy development

The overall aim of the EU Sustainable Development Strategy is to be able to identify and to develop actions that would enable the European Union to achieve a continuing, long-term and prosperous improvement of quality of life. That could be done by creating a sustainable community that is able to manage and use resources efficiently, able to tap the ecological and social innovation potential of the economy and in the end able to ensure prosperity, environmental protection and social cohesion (European Commission, 2015a).

There were a total of 7 main priority challenges until 2010, where most of them were mainly focused on environment:

1. Climate change and clean energy

2. Sustainable transport

3. Sustainable consumption \& production

4. Conservation and management of natural resources

5. Public Health

6. Social inclusion, demography and migration

7. Global poverty and sustainable development challenges

Currently the target for energy efficiency in European Union, set by Energy Union Strategy is $20 \%$ by 2020, which means less than 1086 Mtoe of final energy consumption or less than 1483 Mtoe of primary energy consumption (European Commission, 2015b). This is only $27 \%$ of what is planned for 2030 .

European Union is on track to meet the $20 \%$ of cutting GHG emissions for 2020. In 2014, total estimated EU emissions were 4\% lower than 2013 -around 23\% below 1990 levels and the latest national projections show the EU is heading for a $24 \%$ reduction by 2020 with current measures in place (European Commission, 2015c).

EU climate and energy policies have made a significant contribution to the cuts achieved. The economic crisis contributed to the decrease in emissions, but only to a limited extent. Evaluations confirm that innovation, including progress on renewable energy and energy efficiency, is the main driver behind the emission reductions in recent years (European Commission, 2015c). At the Paris climate conference of COP21, 195 countries adopted the first-ever universal, legally 
binding global climate agreement, which sets out a global action plan to put the world on track to avoid dangerous climate change by limiting global warming to well below $2^{\circ} \mathrm{C}$. This agreement is due to enter into force in 2020 (European Commission, 2016).

\subsection{Indicators of sustainable energy development}

The sustainable development indicators are used in order to monitor the EU sustainable development strategy. There are over 130 indicators that represent sustainable development and 10 of them are identified as headline indicators.

Tab. 1 - Sustainable Development Indicators. Source: Sustainable Development Indicators. (n.d.). Retrieved February 21, 2016, from http://ec.europa.eu/eurostat/web/sdi/indicators

\begin{tabular}{|l|l|}
\hline Theme & Headline indicator \\
\hline $\begin{array}{l}\text { Sustainable } \\
\text { consumption and production }\end{array}$ & Resource (energy) productivity \\
\hline Climate change and energy & $\begin{array}{l}\text { Greenhouse gas emissions } \\
\text { Primary energy consumption }\end{array}$ \\
\hline Sustainable transport & $\begin{array}{l}\text { Energy consumption of transport relative } \\
\text { to GDP }\end{array}$ \\
\hline
\end{tabular}

Table 1 shows the 3 main headline indicators that tell us about the overall picture that European Union has achieved towards sustainable development in terms of the objectives that have been set and the targets that are defined in the EU sustainable development strategy.

Promotion of sustainable consumption and production patterns addresses social and economic development that is bound by the carrying capacity of ecosystems and separates economic growth from environmental degradation. It is an essential requirement for sustainable development.

One of the main issues is unsustainable transport. It brings the biggest challenge to the EU Sustainable Development Strategy. Main objective is to ensure that the transport system can meet the needs for society, it is economically worthy, sustains social and environmental needs while along lowering and minimalizing the impacts that it brings upon the society, economy and environment.

Climate change and energy theme goal is to limit climate change as much as possible while lowering its costs and negative environmental effects that fall on the society. It is very important to follow and see the trends of GHG emissions in each of the member countries as well as overlooking what is the primary energy consumption pattern as it allows us to see and prognoses future for climate change and energy sector.

The main indicators of sustainable energy development presented in table 1 are related to sustainable consumption and production, sustainable transport and climate change and energy. 


\section{COMPARISON OF SUSTAINABLE ENERGY INDICATORS BETWEEN CZECH REPUBLIC, LITHUANIA AND SLOVAKIA}

To understand how sustainable energy development progresses in each country, it is necessary to analyze the data that has been collected through many years. In that way it is possible to see the trends of each indicator and have a short glimpse of what the future for the sustainable energy development may bring to each of Czech Republic, Lithuania and Slovakia.

Sustainable consumption and production mainly identifies as resource productivity as a headline indicator. In our case we will view a certain area of available resources to analyze - energy and its productivity.

Energy productivity indicator is the ratio that is between the gross domestic product (GDP) and the gross inland consumption of energy that is calculated for a calendar year. The indicator measures the productivity of energy consumption of an economy.The gross inland consumption of energy is calculated as the sum of the gross inland consumption of the five types of energy: coal, electricity, oil, natural gas and renewable energy sources (Eurostat, 2015a).

\section{Sustainable consumption and production}

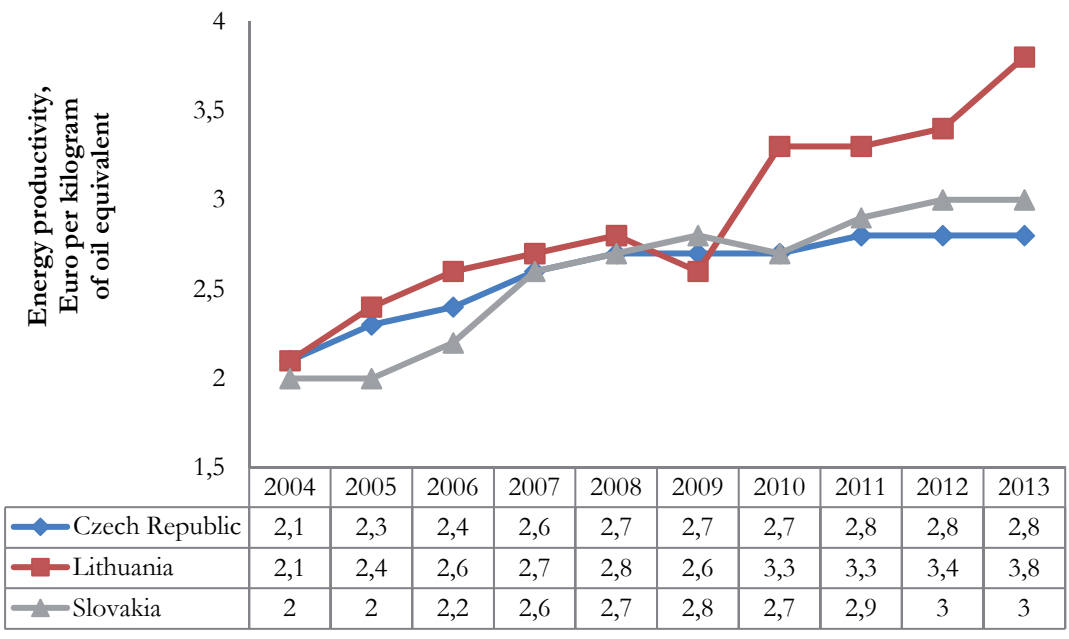

Fig. 1 - Energy productivity. Source: Eurostat. (2015a). Energy productivity. Retrieved February 22, 2016, from http://ec.europa.eu/eurostat/cache/metadata/EN/t2020_rd310_esmsip.htm

From figure 1 it is distinguishable that all three countries - Czech Republic, Lithuania and Slovakia started from the same value $(2.1 ; 2.1 ; 2)$ at the year 2004. Progressing up to year 2009, all values between the countries were very much similar, but after year 2009 to year 2013 it is visible that only Lithuania has managed to exceedingly increase itsenergy productivity, while Czech Republic stayed at 2.8 and Slovakia at 3 euro per kilogram of oil equivalent. 
Climate change and energy is divided into two different comparisons between countries. First is the comparison of GHG emissions in CO2 equivalent and the second one is comparison of the share of renewable energy in gross final energy consumption.

GHG emissions indicator shows the trends in total man-made emissions of the "Kyoto basket" of greenhouse gases (Eurostat, 2015b). It gives a view of annual total emissions that are in relation to the "Kyoto base year" which is 1990 (1995 for F-gases). The Kyoto basket encompasses the following six greenhouse gases: carbon dioxide (CO2), methane ( $\mathrm{CH} 4)$, nitrous oxide $(\mathrm{N} 2 \mathrm{O})$, and the so-called F-gases(hydrofluorocarbons and perfluorocarbons) and sulphur hexafluoride (SF6). Each gas is weighted by its global warming potential and aggregated to give total greenhouse gas emissions in CO2 equivalents (European Commission, 2015d).

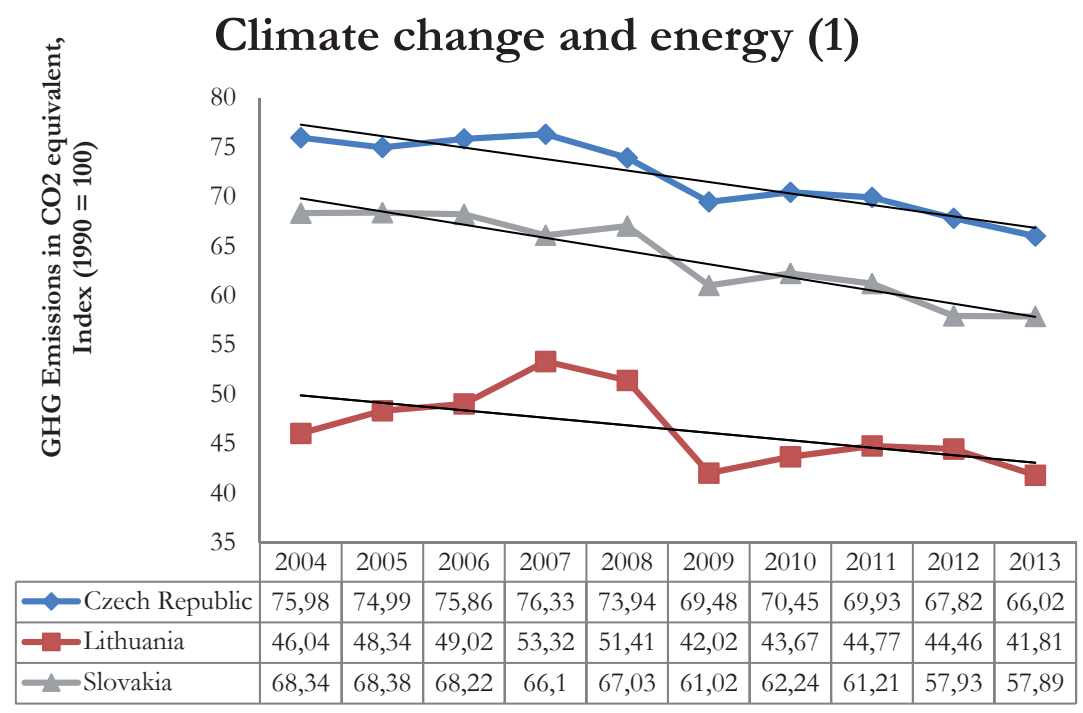

Fig. 2 - Climate change and energy (1). Source: Eurostat. (2015b). Greenhouse gas emissions. Retrieved February 22, 2016, from http://ec.europa.eu/eurostat/cache/metadata/DE/t2020_30_esmsip.htm

Looking at figure 2, it shows that Czech Republic had and has the highest greenhouse gas emissions from all three countries, scoring 75.98 in 2004 and decreasing to 66.02 in 2013 ( $\Delta=-9.96$ ), Slovakia with 68.34 in 2004 and decreasing to 57.89 in 2013 ( $\Delta=-10.45)$.Lithuania had the lowest GHG emissions of 46.04 in 2004 and decreased to 41.81 in 2013 ( $\Delta=-4.25)$.

Trend is for all of the three countries to continue decreasing their GHG emissions as they have been doing so far. In 2012, EU greenhouse gas emissions, including emissions from international aviation, were down by $17.9 \%$ compared with 1990 levels, putting the EU within reach of meeting the Europe 2020 target of reducing GHG emissions by $20 \%$ by 2020 (European Commission, 2015e). 
The second measurement for climate change and energy is the share of renewable energy in gross final energy consumption. The share of renewable sources is calculated from four different indicators:

1. Transport;

2. Heating and cooling;

3. Electricity;

4. Overall renewable source share.

As renewable energy sources are essentially the key to solving climate change issues, it is important that the amount of energy consumed from renewable sources would be higher. It presumably means that the amount of non-renewable energy sources is lower by replacing them with renewable energy sources.

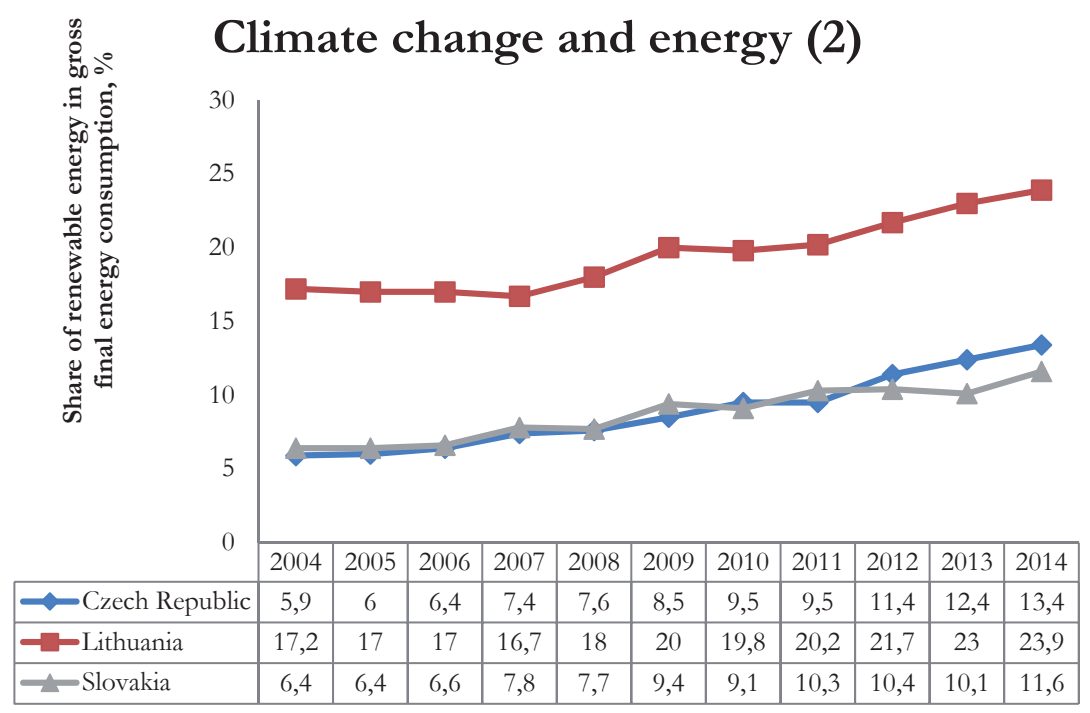

Fig. 3 - Climate change and energy (2). Source: Eurostat. (2015c). Share of renewable energy in gross final energy consumption. Retrieved February 22, 2016, from http://ec.europa.eu/eurostat/cache/metadata/DE/t2020_31_ esmsip.htm

Figure 3 displays an increase of renewable energy shares for all three countries, with Lithuania leading with $17.2 \%$ in 2004 , up to $23.9 \%$ in 2014 ( $\Delta=6.7 \%$ ). Lithuania is followed by the Czech Republic, which started with 5.9\% in 2004 and ended up with $13.4 \%$ in 2014 ( $\Delta=7.5 \%$ ). Slovakia stays third, with $6.4 \%$ in 2004 and $11.6 \%$ in 2014 ( $\Delta=5.2 \%)$.

The highest increase can be detected in the Czech Republic, which means that there has been the highest increase in the share of renewable energy in final energy consumption. Although the Czech Republic has the highest increase, it must be noted that both the Czech Republic and Slo- 
vakia started with $5.9 \%$ and $6.4 \%$ in the year 2004, while in the same year Lithuania already had a share of $17.2 \%$, which is higher than the Czech Republic and Slovakia achieved in the year 2014. Thus, concerning the share of renewable energy in gross final energy consumption, Lithuania is in the lead, with over $10 \%$ of the shares above the Czech Republic and Slovakia.

Sustainable transport is identified with the energy consumption of transport relative to GDP. This indicator defines the ratio between the energy that is consumed by transport and GDP. All types of transport are included. This indicator aims to compare the growth of the energy consumption of transport with that of GDP at the same prices.

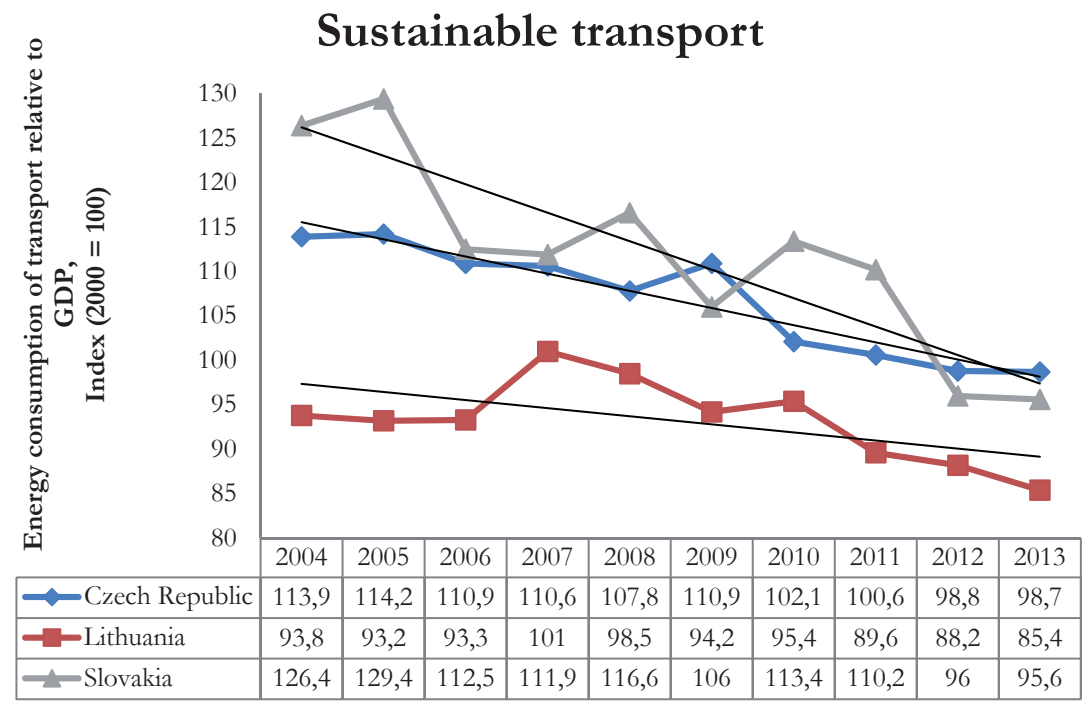

Fig. 4 - Sustainable transport. Source: Eurostat. (2015d). Energy consumption of transport relative to GDP. Retrieved February 22, 2016, from http://ec.europa.eu/eurostat/cache/metadata/DE/tsdtr100_esmsip.htm

Figure 4 displays how volatile the data between the Czech Republic, Lithuania, and Slovakia is. It is evident that all three countries have reduced the energy consumption of transport compared to GDP, with Lithuania the lowest, starting at 93.8 in 2004 and ending at 85.4 in $2013(\Delta=8.3)$. The country that had the second lowest result is the Czech Republic, with 113.9 in 2004 and 98.7 in 2013 ( $\Delta=15.2$ ). Slovakia has been surpassed by the Czech Republic in the long run, with 126.4 in 2004 and 95.6 in 2013 ( $\Delta=30.8)$, but had the lowest decrease in the nine-year period, doubling the amount compared to the Czech Republic and nearly four times more than Lithuania. All three countries show a trend to reduce their energy consumption of transport relative to GDP. 


\section{CONCLUSIONS}

During the work, the concept of sustainable energy development has been established. It was concluded that sustainable energy development is a development that can meet the needs of resources for people nowadays without compromising the needs of future generations. It was also established that the European Commission provides policies that promote sustainable energy development in all the countries of the European Union, including the Czech Republic, Lithuania, and Slovakia. The main objectives are set out in the EU 2020 programme.

The sustainable energy development indicators that are used to compare the countries in the work are energy productivity, greenhouse gas emissions, final energy consumption, and the energy consumption of transport relative to GDP.

Energy productivity (Euro per kilogram of oil equivalent) between the Czech Republic, Lithuania, and Slovakia has the highest rating in Lithuania with 3.8 in 2013, followed by Slovakia with 3 and then the Czech Republic with 2.8 in 2013. Trends for energy productivity are continuing to rise in all three countries.

The lowest greenhouse gas emissions are detected in Lithuania, with a value of 41.81 followed by Slovakia with 57.89 and the Czech Republic with 66.02 in 2013. The trends for climate change and energy themes main headline indicator of greenhouse gas emissions are set to continue decreasing within years and meeting the EU 2020 target.

The share of renewable energy in gross final energy consumption depends on the extent to which renewable energy sources are being used. So far Lithuania has the highest share of renewables compared to the final energy consumption. In comparison with the Czech Republic and Slovakia, Lithuania has a value of $23.9 \%$, which is more than twice that in Slovakia - 11.6\% - and also nearly twice that in the Czech Republic $-13.4 \%$.

The energy consumption of transport relative to the GDP index showed that Slovakia has greatly reduced its value, by 30.8 between 2004 and 2013. Next follows the Czech Republic, with a decrease of 15.2, and then Lithuania, with a decrease of 8.3 between the years 2004 and 2013. Still, the lowest rating of all three countries in 2013 is for Lithuania, with 85.4, and then, not too far away, Slovakia with 95.6 and the Czech Republic with 98.7.

Our hypothesis has been confirmed, showing that there is positive feedback in each of the sectors under analysis regarding sustainable energy development in the Czech Republic, Lithuania, and Slovakia. This means that the policies implemented in each of the countries regarding sustainable development have been successful and brings a promise that in the future sustainable energy development will increase and grow.

The comparison between the three countries shows how each country is progressing towards more sustainable energy development, while comparing one with the other and seeing what the trends are for the future, which sector is gaining more strength, and where there is a need for an improved development to take place in the future. 


\section{References}

1. Afgan, N. H., Carvalho, M. G., \& Hovanov, N. V. (2000). Energy system assessment with sustainability indicators. Energy Policy, 28(9), 603-612. http://doi.org/10.1016/S03014215(00)00045-8

2. Ahuja, D., \& Tatsutani, M. (2009). Sustainable energy for developing countries. S.A.P.I.EN.S. Surveys and Perspectives Integrating Environment and Society, (2.1). Retrieved from https://sapiens.revues.org/823

3. Banos, R., Manzano-Agugliaro, F., Montoya, F. G., Gil, C., Alcayde, A., \& Gómez, J. (2011). Optimization methods applied to renewable and sustainable energy: A review. Renewable and Sustainable Energy Reviews, 15(4), 1753-1766.

4. Barbier, E. B. (1987). The Concept of Sustainable Economic Development. Environmental Conservation, 14(02), 101 - 110. http://doi.org/10.1017/S0376892900011449

5. Brundtland, G., Khalid, M., Agnelli, S., Al-Athel, S., Chidzero, B., Fadika, L, et al. (1987). Our Common Future ('Brundtland report'). USA: Oxford University Press.

6. Cicea, C., Marinescu, C., Popa, I., \& Dobrin, C. (2014). Environmental efficiency of investments in renewable energy: Comparative analysis at macroeconomic level. Renewable and Sustainable Energy Reviews, 30, 555-564.

7. European Commission. (2015a). Sustainable Development. Retrieved February 21, 2016, from http://ec.europa.eu/environment/eussd/

8. European Commission. (2015b). Progress made on 2020 energy efficiency target - Energy - European Commission. Retrieved February 21, 2016, from https://ec.europa.eu/energy/en/news/ progress-made-2020-energy-efficiency-target

9. European Commission. (2015c). Progress made in cutting emissions. Retrieved February 21, 2016, from http://ec.europa.eu/clima/policies/strategies/progress/index_en.htm

10. European Commission. (2015d). Kyoto basket. Retrieved February 22, 2016, from http:// ec.europa.eu/eurostat/statistics-explained/index.php/Glossary:Kyoto_basket

11. European Commission. (2015e). Climate change and energy. Retrieved February 22, 2016, from http://ec.europa.eu/eurostat/web/sdi/indicators/climate-change-and-energy

12. European Commission. (2016). Paris Agreement. Retrieved February 21, 2016, from http:// ec.europa.eu/clima/policies/international/negotiations/paris/index_en.htm

13. Eurostat. (2015a). Energy productivity. Retrieved February 22, 2016, from http://ec.europa. eu/eurostat/cache/metadata/EN/t2020_rd310_esmsip.htm

14. Eurostat. (2015b). Greenhouse gas emissions. Retrieved February 22, 2016, from http:// ec.europa.eu/eurostat/cache/metadata/DE/t2020_30_esmsip.htm

15. Eurostat. (2015c). Share of renewable energy in gross final energy consumption. Retrieved February 22, 2016, from http://ec.europa.eu/eurostat/cache/metadata/DE/t2020_31_esmsip.htm

16. Eurostat. (2015d). Energy consumption of transport relative to GDP. Retrieved February 22, 2016, from http://ec.europa.eu/eurostat/cache/metadata/DE/tsdtr100_esmsip.htm 
17. Ibáñez-Forés, V., Bovea, M. D., \& Pérez-Belis, V. (2014). A holistic review of applied methodologies for assessing and selecting the optimal technological alternative from a sustainability perspective. Journal of Cleaner Production; 70: 259-281.

18. Munasinghe, M. (2007). Economic, social, and environmental elements of development. The Encyclopedia of Earth. Retrieved from http://www.eoearth.org/view/article/151937/

19. Streimikiene D. (2013). Assessment of road transport technologies based on GHG emission reduction potential and costs. Transformation in Business and Economics, 12 (29), 138-148.

20. Streimikiene D, Balezentiene L. (2012). Assessment of Electricity Generation Technologies Based on GHG Emission Reduction Potential and Costs.Transformation in Business and Economics, 11 (2A), 333-344.

21. Streimikiene D., Sarvutyte-Grigaliuniene. (2013). Impact of renewables on employment in Lithuania. Transformations in business and economics, 11(1), 167-184.

22. Streimikiene D, Mikalauskiene A, Barakauskaite-Jakubauskiene (2011). Sustainability Assessment of Policy Scenarios. Transformation in Business and Economics, 10 (2), 168-165.

23. Streimikiene, D., Bruneckiene, J., Cibinskiene. A. (2013). The Review of Electricity Market Liberalization Impacts on Electricity Prices, Transformations in Business and Economics, 12 (3), 40-61.

24. Sustainable Development Indicators. (n.d.). Retrieved February 21, 2016, from http://ec.europa. $\mathrm{eu} /$ eurostat/web/sdi/indicators

25. Vasauskaite J, Streimikiene D. (2014). Review of Energy Efficiency Policies in Lithuania. Transformations in business and economics, 13, 628-643.

\section{Contact information}

Prof. dr. Dalia Streimikiene

Vilnius University

Kaunas Faculty of Humanities

Muitines 8, Kaunas, Lithuania

E-mail:dalia.streimikiene@kkbf.vu.lt

Assoc prof. dr. Asta Mikalauskiene

Vilnius University

Muitines 8, Kaunas, Lithuania

E-mail: asta.mikalauskiene@k.kf.vu.lt

Ing. Ignas Mikalauskas

Vilnius University

Muitines 8, Kaunas, Lithuania

E-mail:ignas.mikalauskas@gmail.com 